Future-Proofing Japan's Interests in the Arctic

Scientific Collaboration and a Search for Balance

Tonami, Aki

Published in:

Asia Policy

DOI:

10.1353/asp.2014.0027

Publication date:

2014

Citation for published version (APA):

Tonami, A. (2014). Future-Proofing Japan's Interests in the Arctic: Scientific Collaboration and a Search for Balance. Asia Policy, 18(1), 52-58. https://doi.org/10.1353/asp.2014.0027 


\section{ROUNDTABLE}

Polar Pursuits: Asia Engages the Arctic

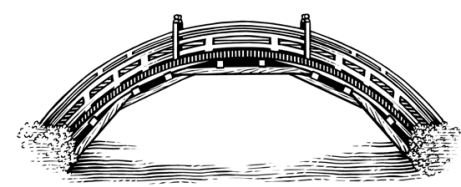

Michael Wills

Lawson Brigham

James Kraska

P. Whitney Lackenbauer

Katarzyna Zysk

Leiv Lunde

Kai Sun

Aki Tonami

Young Kil Park

Ian Storey

Sanjay Chaturvedi 


\title{
Future-Proofing Japan's Interests in the Arctic: Scientific Collaboration and a Search for Balance
}

\author{
Aki Tonami
}

I n May 2013 the Arctic states convened in Kiruna, Sweden, in part to decide on whether six new states should be admitted as observers to the Arctic Council. Japan's application was accepted along with those of China, India, Italy, Singapore, and South Korea. At a glance, one might ask what credentials Japan has to be involved in the leading Arctic forum. However, a closer look at its engagement in the Arctic indicates that Japan has genuine interests in political, economic, and environmental developments there. This essay examines Japan's interests in the Arctic, its new role as an observer to the Arctic Council, and the international relationships that will affect Japan's engagement in the region.

\section{Japan's Current Engagement in the Arctic}

Japan is no newcomer to the Arctic. Already in 1925, the country became one of the fourteen high-contracting parties to the Spitsbergen Treaty, which recognizes the sovereignty of Norway over the Arctic archipelago of Svalbard. In 1990, Japan formally joined the Arctic research community by becoming a member of the International Arctic Science Committee (IASC) as a non-Arctic state. In the same year, the Centre for Arctic Research at the National Institute of Polar Research (NIPR) was established in Japan.

According to the Japanese government, the country's primary aim of engagement in the Arctic has been and remains understanding and protecting the natural environment. ${ }^{1}$ As the negative impacts of climate change became more apparent, policies related to scientific research were given higher priority. Since May 2011, the NIPR has led a nationwide project that seeks to integrate the various strands of Japanese scientific research related to climate change in the Arctic. ${ }^{2}$ In addition, since Japan made the

AKI TONAMI is a Researcher at the Nordic Institute of Asian Studies (NIAS) at the University of Copenhagen in Denmark. She can be reached at<aki.tonami@nias.ku.dk>.

\footnotetext{
1 Ministry of Foreign Affairs (Japan), "Hokkyoku: Kanosei to kadai no motarasu mirai" [The Arctic: The Future Arising from the Opportunities and Challenges], December 25, 2013 \& http://www.mofa.go.jp/mofaj/press/pr/wakaru/topics/vol107.

2 National Institute of Polar Research, “To the Arctic...Where You Can See the Future of the Earth," October $2011 \approx$ http://www.nipr.ac.jp/grene/doc/grene_E.pdf.
} 
decision to prioritize becoming an observer in the Arctic Council, the region has gained a certain level of political momentum and Japan's Arctic policies have started to gather pace and shape. For instance, just before the council's decision, an Arctic ambassador was assigned by Japan's Ministry of Foreign Affairs (MOFA) in March 2013, and the Arctic was included in the central government's new Basic Plan on Ocean Policy, published in April 2013. ${ }^{3}$

This greater focus on the Arctic can be partly attributed to a stronger lobby from the Ocean Policy Research Foundation (OPRF). OPRF is a think tank and lobbying organization for the Japanese shipping and manufacturing industries and has conducted several research projects on the Arctic, especially regarding the Northern Sea Route (NSR). Guided by the Basic Plan on Ocean Policy, a new interministerial committee on the Arctic (called Hokkyokukai Ni Kakaru Shomondai Ni Taisuru Kankei Shocho Renraku Kaigi, or the Liaison Committee among Ministries and Agencies on Various Issues Related to the Arctic) was set up in July 2013. The Ministry of Land, Infrastructure, Transport and Tourism (MLIT) - one of the more proactive and powerful ministries of Japan-has also shown an interest in the Arctic. In 2013, MLIT conducted a small project to study the practical legal implications of using the NSR along the Russian coast, with a view toward developing the sea route further. More recently, in January 2014, OPRF began collaborating with MLIT and the Ministry of Education, Culture, Sports, Science and Technology (MEXT) on a new project to specifically consider the construction of a new icebreaker for Arctic observations. ${ }^{4}$

\section{Japan's Reasons for Joining the Arctic Council}

Japan's decision to apply for observer status on the Arctic Council came at a time when the council was beginning to take on new responsibilities. As the Arctic region underwent climate changes, the council's adoption of new roles related to safety of navigation and search and rescue was taken as an indication that the council itself was changing and that the positions of member states were shifting. ${ }^{5}$ The council is the only formal mechanism in the Arctic similar to the Antarctic Treaty System. As a major maritime

\footnotetext{
3 Cabinet Office (Japan), “Kaiyo kihon keikaku” [Basic Plan on Ocean Policy], April 2013.

4 "Hokkyoku kansokusen, seifu ga shinzo kento koro katsuyo, deokure bankai" [The Government Considers Building a New Arctic Observation Ship: Catch Up on Using the Sea Route], Sankei Shimbun, January 26, $2014 \curvearrowright$ http://sankei.jp.msn.com/life/news/140126/trd14012614110012-n1.htm.

5 Author's interview with an official at the Ministry of Foreign Affairs, Tokyo, February 17, 2012.
} 
nation with a long history of polar research, Japan could not overlook the importance of participation in formal discussions regarding the Arctic. At the same time, Tokyo recognized that it did not have a legal basis to participate in such discussions other than through the United Nations Convention on the Law of the Sea (UNCLOS). Until it was able to gain observer status, Japan regarded it as important to at least be a part of the decision-making process and contribute to ongoing scientific research and the development of resources, sea routes, trade, and technology related to the Arctic. ${ }^{6}$

This decision was not motivated by immediate security threats or economic interests. Japan judged that the potential for security problems in the Arctic is minimal, unless relations between China and Russia or Russia and the United States become severely strained. ${ }^{7}$ Hence, it was not particularly concerned that the council does not have a mandate to discuss national or international security matters. Moreover, based on previous research findings from OPRF, the Japanese shipping industry had concluded long before that any benefits from developing the NSR were too fragile to present significant financial or logistical advantages over existing routes. Instead, Japan regarded its decision to join the Arctic Council and collaborate with Arctic states on research and development as a step to secure future rather than present interests. ${ }^{8}$

\section{Japan's Contributions to the Arctic Council}

In Japan's view, scientific research is what it does best as a technologically advanced industrial nation. Japan also believes that this is what the Arctic Council expects it to do. The natural environment of the Arctic is fragile and requires large-scale, costly research in order to understand the possible repercussions of climate change. In terms of capacity at present, Japan owns three icebreakers, but only the Shirase possesses the capacity to be used as an icebreaker for Arctic expeditions. However, the Shirase is operated by the Japan Maritime Self-Defense Force and under current law can only be used as a supply vessel for the Japanese Antarctic Research Expedition (JARE). ${ }^{9}$

\footnotetext{
6 Author's interview with Tetsuo Kotani, Tokyo, November 6, 2012.

7 Author's interview with researchers at the National Institute of Defense Studies, Tokyo, October 22, 2012.

8 Aki Tonami and Stewart Watters, "Japan's Arctic Policy: The Sum of Many Parts," in Arctic Yearbook 2012, ed. Lassi Heininen (Akureyri: Northern Research Forum, 2012).

9 For more details, see ibid.
} 
The purpose of the ongoing discussion between OPRF, MEXT, and MLIT on building an Arctic-specific icebreaker is to overcome this legal restriction in order to further promote Japan's Arctic scientific research. The Arctic ambassador, Toshio Kunikata, mentioned in his presentation at the Arctic Frontiers conference in 2014 that Japan, as a maritime nation surrounded by water, could additionally contribute its expertise to the search-and-rescue efforts of the member states of the Arctic Council.

Japan could also take the lead in promoting intra-Asia cooperation on the Arctic, which would benefit both the member states of the Arctic Council and the five new Asian observers. This initiative would save the member states time and effort, as there would be less need for them to have separate bilateral relations on the Arctic with each of the Asian states. All Asian observers, particularly the three East Asian states (China, Japan, and South Korea), would greatly benefit from cooperating with each other to develop the ports and necessary infrastructure to make the NSR a functioning reality. Although for the time being historical grievances, territorial disputes, and mutual suspicion are hindering the prospects for such cooperation, the Arctic Council gives Japan and other Asian countries a forum in which to meet and informally discuss opportunities for Arctic cooperation.

\section{Building Greater Cooperation}

with China, Russia, and the United States

China. The consensus among Japanese scientists and business people engaged in the Arctic is that cooperation with China is important given the limits on what Japan can accomplish by itself. Interactions among scientists from the two countries already occur at academic conferences as well as during Antarctic expeditions, as both the Chinese and Japanese polar research centers have stations in Antarctica. ${ }^{10}$ One Japanese scholar has pointed out that in order for the NSR to be truly effective, port facilities need to be improved in order to provide refuge to ships during emergency situations, both a search-and-rescue system and the infrastructure for it must be further developed, and hydrographic charts must be updated. ${ }^{11}$ Given the cost of all three of these measures, the Chinese and Japanese shipping industries recognize that further cooperation would definitely

10 Author's interview with a professor at the Polar Research Institute of China, Shanghai, June 5, 2013.

11 Natsuhiko Otsuka, "Will the Northern Sea Route See a Bright Future?” (lecture at the Nordic Institute of Asian Studies, Copenhagen, January 27, 2014). 
benefit both sides. As mentioned earlier, however, political tension and mistrust between the two countries hinder scientific and commercial cooperation. Both the Chinese and Japanese media and governments are keenly aware of each other's Arctic-related activities, as if to compete against each other. ${ }^{12}$

Russia and the United States. Japanese experts are divided on whether Russia or the United States is the best partner for Japan in the Arctic arena. For example, OPRF believes that Russia is the most important stakeholder for Japan's engagement in the Arctic. Among its nine specific policy recommendations made in 2012 regarding the Arctic, OPRF suggested that the government set up a formal mechanism for the two countries to discuss Arctic affairs. ${ }^{13}$ However, the Japan Institute of International Affairs (JIIA), which is one of the most influential Japanese think tanks and has strong links to MOFA, argued differently. In its policy recommendations released in 2012, JIIA emphasized the promotion of peaceful and stable Arctic governance based on the international order but nonetheless recommended that Japan-U.S. cooperation be strengthened, particularly in terms of security, considering possible changes to the strategic environment. ${ }^{14}$

Despite these conflicting opinions among stakeholders, until the Ukraine crisis it appeared that Japan leaned more toward Russia than the United States as an Arctic partner. This view was supported by several factors. First, Moscow has made developing its isolated eastern territories, especially the Russian Far East, a high national priority, thereby increasing its eagerness to engage in joint development projects with countries like Japan. ${ }^{15}$ Second, since Prime Minister Shinzo Abe returned to power in 2012, he has prioritized the bilateral relationship between Japan and Russia. As Yoko Hirose has noted, this is the result of a shift in Japanese foreign policy toward "value-based diplomacy" (kachikan gaiko), which itself is based on the U.S.-Japan alliance and the concept of the "arc of freedom

\footnotetext{
12 See "Riben sheli zhu Beiji dashi, ni tigao zai Beiji 'cunzai gan" [Japan Assigns the Arctic Ambassador: To Increase the "Presence" in the Arctic], Huanqiu, March 19, $2013 \approx$ http:// world.huanqiu.com/exclusive/2013-03/3747218.html; and Okazaki Kenkyujo, "Hokkyokuken ni okeru Chugoku no omowaku" [China’s Calculation in the Arctic] $\approx$ http://wedge.ismedia.jp/ articles/-/2903.

13 Ocean Policy Research Foundation, "Hokkyokukai no jizokukano na riyo ni muke Nippon ga tadachi ni okonaubeki sesaku" [Policies That Japan Should Implement Immediately for the Sustainable Use of the Arctic], 2012.

14 Japan Institute of International Affairs (JIIA), "Hokkyoku no gabanansu to Nippon no gaiko senryaku” [The Arctic Governance and Japan's Diplomatic Strategy], 2012, 98.

15 Rensselaer Lee, "The Russian Far East: Opportunities and Challenges for Russia's Window on the Pacific," Orbis 57, no. 2 (2013): 314-24.
} 
and prosperity" from the first Abe administration (2006-7). ${ }^{16}$ Russia is considered to be within this arc. Third, Tokyo has a clear motive to work with Moscow to increase gas imports as Japan became more dependent on liquefied natural gas (LNG) after the Fukushima nuclear accident in 2011 and the subsequent nationwide shutdown of nuclear power plants. ${ }^{17}$ Finally, the U.S. approach to the Arctic is viewed in Japan as being mostly centered on achieving security rather than commercial goals, the latter of which Japan regards as more relevant. ${ }^{18}$

\section{Challenges Confronting Japan as \\ It Attempts to Interact in the Arctic}

Against this backdrop, the recent illegal annexation of Crimea by Russia has placed Japan in a difficult position, especially in light of the positive relationship between Putin and Abe. Their closeness is considered exceptional, given the fact that Japan has a long-standing territorial dispute with Russia and no peace treaty was reached between the two countries following the end of World War II. ${ }^{19}$ Business development in the Russian Arctic is one of the few areas where both countries could benefit from furthering their relationship. Therefore, finding the right level of cooperation with Russia, while maintaining the U.S.-Japan alliance and fulfilling its obligations as a member of the group of seven (G-7), will be a difficult balancing act for Japan. In the meantime, despite the divisions over Ukraine, there are signs that Japan is attempting to promote commercial cooperation in the Arctic with Russia while avoiding giving offense to the United States. For example, the Japan-Finland Business Forum, which promoted Finland as a "center of Europe and gateway to Russia," was held in Helsinki and St. Petersburg in May 2014, backed by the Finnish and Japanese governments.

In addition to pursuing cooperation with Russia in the Arctic, as mentioned earlier, it would be beneficial for Japan to improve trilateral cooperation with China and South Korea in dealing with the Arctic Council.

\footnotetext{
16 Yoko Hirose, “Abe seiken no Roshia, kyu Soren chiiki no gaiko seisaku” [The Abe Administration's Dipmatic Policy Toward Russia and the Former Soviet Region], Synodos, August 6, $2013 \approx$ http:// synodos.jp/international/5124.

17 Atle Staalesen, "French, Japanese Technology for Yamal LNG”, Barents Observer, April 3, 2013 \& http://barentsobserver.com/en/energy/2013/04/french-japanese-technology-yamal-lng-03-04.

18 JIIA, "Hokkyoku no gabanansu to Nippon no gaiko senryaku," 85.

19 “Japan's Relations with Russia: The End of the Affair," Economist, March 17, $2014 \approx$ http://www. economist.com/blogs/banyan/2014/03/japans-relations-russia.
} 
Although China and South Korea are more eager than Japan to develop the NSR and natural resources in the Arctic, the three countries share concerns regarding navigation rights. China and South Korea have already made a bilateral research agreement regarding the Arctic. As important as Russia and the United States are for Japan's engagement in the Arctic, it would be unwise for Japan to ignore the opportunity this presents. Overcoming the political tension and mistrust with both China and South Korea will thus be key for Japan to achieve its goals in the Arctic. $\diamond$ 